\title{
Use of bacterial cellulose as a fat replacer in emulsified meat products: review
}

\author{
Alyne Alves Nunes OLIVEIRA ${ }^{1 *}$ (D), Eliana de Fátima Marques de MESQUITA ${ }^{1}$, Angela Aparecida Lemos FURTADO²
}

\begin{abstract}
Emulsified meat products have a high fat content. The industry has been looking for strategies to replace fat with healthier products in order to meet consumer demands. This review aims to present studies on the use of BC as a substitute in emulsified meat products. In these studies, BC proved to be a potential fat replacer, as it maintained the same technological and sensory properties found in products with original fat content.
\end{abstract}

Keywords: Komagataeibacter xylinus; nata-de-coco; meat products; low-fat meat products; fat replacers.

Practical Application: Review of articles that used bacterial cellulose as fat replacer in meat products.

\section{Introduction}

It is known that emulsified meat products have a high content of saturated fat, which is related to cardiovascular diseases, diabetes, among others. The growing consumer concern about food has led to the development of healthier emulsified meat products, based on the reformulation of the saturated fatty acid profile (Gómez-Estaca et al., 2019; Kumar, 2021). In this type of product, fat can be partially or totally replaced by low-energy ingredients. However, this manipulation can cause adverse effects on quality and, therefore, the replacement of fat is a major challenge for the industry (Varga-Visi \& Toxanbayeva, 2017)

Bacterial cellulose $(\mathrm{BC})$ is a promising ingredient as a substitute for fat, which can be produced by different bacteria, and Komagataeibacter xylinus is one of the most efficient (ArserimUçar et al., 2021; Lima et al., 2018). For Shi et al. (2014), BC is a multifunctional additive due to its ability to improve the texture of foods, in addition to producing them with low calories and low cholesterol, and therefore healthier (Li et al., 2020). This review study aims to evaluate the current scenario in the research of bacterial cellulose as a replacer in emulsified meat products.

The search for articles was carried out in July 2020, with no restriction on the date of publication and in English, Spanish, among other languages. The literature review was based on a bibliographic survey using the MEDLINE (Medical Literature Analysis and Retrieval System Online), PubMed (National Library of Medicine), ScienceDirect, Scopus and Web of Science databases. Google Scholar (GS) was also used in the search for grey literature and to identify additional articles. The search strategy for the articles selected in Table 1 was made using two blocks, the first using terms related to bacterial cellulose ("bacterial cellulose", "nata de coco" (a creamy yellow product) and products of animal origin ("meat products", "meat derivates"). For the combination of terms, Boolean operator "OR" was used in each block and operator "AND" for combination between the blocks. The collected articles were exported to Mendeley Desktop 1.19.4 (MendeleyLtd, London, UK).

\section{Emulsified products}

Emulsions are thermodynamically unstable systems and, as the contact between oil and water molecules is unfavorable, they can break down over time. In the preparation of kinetically stable emulsions over time, mainly in the food industry, "emulsifiers" or "texture modifiers" are necessary (Calvo et al., 2020; McClements, 2007). Meat emulsion is a system composed of two or more immiscible phases. This emulsion can be defined as a three-dimensional (3D) network formed by interactions of proteins, fat, water, salts and other components (Santos et al., 2020; Rodrigues et al., 2020).

The preparation of the paste is an important step in the process of obtaining emulsified meat products such as mortadella. The term "meat batters" is more used in the industry when referring to emulsified meat products (Jiang \& Xiong, 2015). The meat emulsion is formed by cutting the meat and, subsequently, with the addition of salt, phosphates and water. This process activates the muscle protein by disrupting the sarcolemma to release myofibrillar proteins, actin and myosin. Myofibrillar proteins have emulsifying properties and interact with other non-meat ingredients, affecting the technological properties of meat emulsion, such as water and fat holding capacities, stability of emulsion and rheological parameters (Kumar, 2021; Marchetti \& Andrés, 2021).

The interaction between water, protein and fat particles is the main factor responsible for the desired quality and the structural organization of an emulsified meat product. The mixture of these finely crushed ingredients and the heat applied through cooking cause protein denaturation, resulting in a homogeneous meat product (Gordon, 1993; Pereira et al., 2020). 
Table 1. Recent studies with application of BC in meat products.

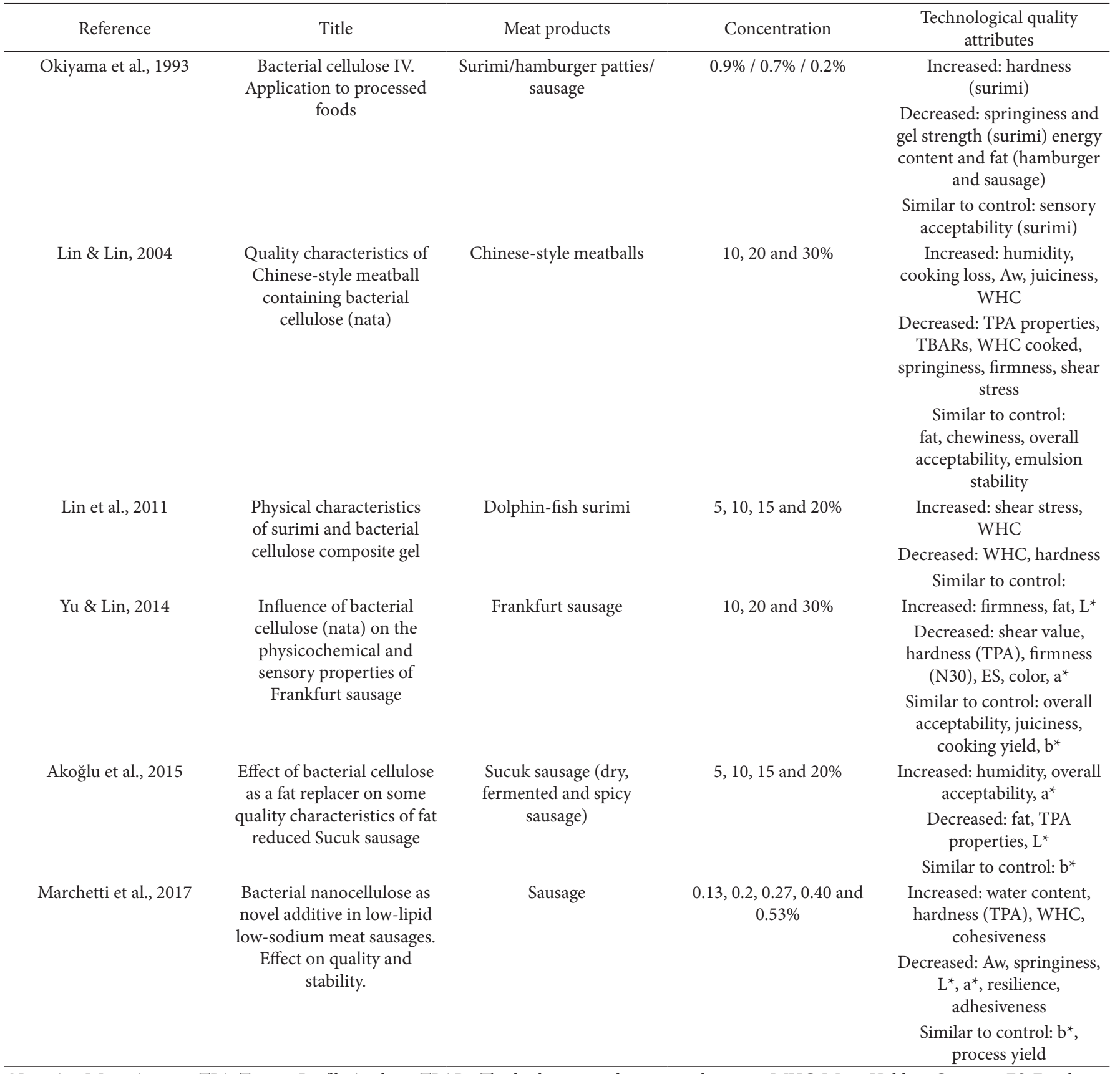

Note. Aw: Water Activity; TPA: Texture Profile Analysis; TBARs: Thiobarbituric acid reactive substances; WHC: Water Holding Capacity; ES: Emulsion Stability; N30: $30 \%$ nata.

Emulsified meat products have a high fat content (about 20-35\% saturated fat) (Câmara et al., 2020; Pinton et al., 2019). Fat plays a fundamental role in the technological quality of these products, such as the stabilization of the emulsion, improving the water holding capacity during cooking, in addition to promoting juiciness and firmness (Choi et al., 2009; Öztürk-Kerimoğlu et al., 2020). Fat is an important source of essential fatty acids, linoleic acid (Omega-3) and linolenic acid (Omega-6), in addition to its key role in maintaining healthy skin, regulating cholesterol metabolism and as a precursor to prostaglandins. It is a fundamental nutrient in the transport of fat-soluble vitamins A, D, E and K, and also in the aid of its absorption by the intestine (Warshaw et al., 1996; Tufeanu \& Tita, 2016).

Moderate fat intake is beneficial, but excessive consumption is related to chronic diseases, such as cardiovascular diseases, obesity and diabetes (Kim et al., 2021; Silva-Vazquez et al., 2018; Szpicer et al., 2020). The consumption of saturated fat should correspond to less than $10 \%$ of the total caloric intake, with the lowest possible consumption of trans fat and replacing saturated fat with mono and polyunsaturated fats (López-Pedrouso et al., 2021; Tufeanu \& Tita, 2016). 
In recent years consumers have become more concerned about health and nutrition, and therefore are changing eating habits towards healthier foods (Kwon et al., 2021; Szpicer et al., 2020). According to Kumar (2021) the healthy food market is expected to grow enormously in the next decade, being driven by health concerns. Due to this new trend in consumption the industry has been looking for several strategies to develop meat products with low saturated fat content (Barbut et al., 2019; Kwon et al., 2021). However, the reformulation of these products can cause changes in technological parameters, such as emulsion stability, water holding capacity, loss of water and fat during cooking, and therefore, it can alter sensory characteristics, such as taste, odor, mouthfeel, juiciness and general acceptance of the product (Álvarez \& Barbut, 2013; Kumar, 2021; Marchetti et al., 2017). Moreover, the reduction or substitution of fat can cause an increase in the cost of the final product (Bolger et al., 2017).

To reduce fat and preserve the technological and sensory characteristics of the emulsified meat product, studies are investigating the use of new ingredients to replace fat. These ingredients are fat substitutes that guarantee the same technological characteristics provided by fat. These ingredients must also be recognized as safe and healthy to ensure the functionality of the replaced fat (Kumar, 2021; Tufeanu \& Tita, 2016). According to Varga-Visi \& Toxanbayeva (2017) a substitute must provide fewer calories than the fat used, but the resulting product must have technological and sensory properties similar to commercial products.

In fat replacement, several strategies have been tested to improve the lipid profile of formulations. Substitutes are classified by their composition: based on proteins, carbohydrates or lipids (Brewer, 2012; Yousefi et al., 2018). Most carbohydrate-based substitutes are dietary fibers and modified or resistant starches. Protein-based substitutes come from milk, eggs or vegetables. Lipid-based substitutes are used to improve the composition of fatty acids (Varga-Visi \& Toxanbayeva, 2017).

Therefore, it is crucial to unveil the interactions between the ingredients and the ways in which they can be used in formulations for the preparation of stable products (Câmara et al., 2020). To reproduce the different functions of fat in this type of product, it is necessary to consider texture, oral sensation of the food, consistency, color and taste perception (Felfoul et al., 2015). The physicochemical characteristics of fat substitutes must be considered as they play a major role in the quality properties of reformulated products (Fan et al., 2020).

\section{Bacterial Cellulose}

Cellulose is a natural polymer that has a molecular formula $\left(\mathrm{C}_{6} \mathrm{H}_{10} \mathrm{O}_{5}\right)_{\mathrm{n}}$ and consists of $ß \mathrm{p}(1 \rightarrow 4)$ units linked to D-glucose (Dong et al., 2021; Güzel \& Akpınar, 2020). It is the most abundant biocompatible organic product in nature, found in the cell wall of plant cells and has several applications in the food, textile, paper, pharmaceutical and medicine industries (Arserim-Uçar et al., 2021; Volova et al., 2018). However, it needs to be purified before it can be used to remove hemicellulose and lignin through enzymatic, chemical or mechanical treatments. These processes have a high economic and environmental cost, in addition to altering the functionality of cellulose and limiting its applicability (Fernández et al., 2019).

Some bacteria have attracted attention as an alternative and sustainable source of cellulose. Cellulose synthesized by bacteria was called bacterial cellulose to be distinguished from plant-derived cellulose (Fernández et al., 2019; Pang et al., 2020). According to Lima et al., (2018), depending on the context in which it is used, bacterial cellulose may be given different names, for example, "mother of vinegar", "nata de coco" Zoogloea or biocellulose.

Bacterial cellulose is a linear-chain polysaccharide with the same chemical structure as vegetable cellulose (Gallegos et al., 2016). However, bacterial cellulose has advantages regarding physicochemical and mechanical properties, such as tensile strength, thermostability, biocompatibility, high water holding capacity, greater purity due to the absence of hemicellulose and lignin, high degree of polymerization, greater crystallinity (about 70 to $80 \%$ ) and mechanical stability (Gallegos et al., 2016; Guo et al., 2018; Zhai et al., 2018).

According to Jozala et al. (2016), the biochemical process of the synthesis consists of three stages: first, the carbon compounds of the nutrition medium used by the bacteria are polymerized in linear chains of $\beta$-1.4-glucan, then there is the extracellular secretion of linear chains, and finally the organization and crystallization of glucan chains through hydrogen bonds and Van der Waals forces arranged in strips (Shi et al., 2014). BC is a biopolymer that has glucose monomers linked by $\beta-1.4$ glycosidic bonds with a three-dimensional arrangement formed by $1.5 \mathrm{~nm}$ subfibrils mounted on 2-4 nm nanofibrils and organized on 40-60 nm nanofibers (Alves et al., 2016; Cacicedo et al., 2016), as shown in Figure 1.

BC was discovered in 1886 by A. J. Brown, who observed the formation of a gelatinous blanket on the surface of the vinegar fermentation broth. The identified structure was chemically similar to vegetable cellulose, and by microscopic analysis, the presence of bacteria distributed throughout the surface area of the film, identified as Acetobacter xylinum (Brown, 1886; Klemm et al., 2001) was revealed.

$\mathrm{BC}$ is an extracellular polysaccharide that can be produced by several bacteria, including Agrobacterium, Pseudomonas, Rhizobium, Escherichia, Sarcina, Salmonella, Alcaligenes, Achromobacter, Azotobacter, Aerobacter and Komagataeibacter (Jacek et al., 2019; Naloka et al., 2020). Acetobacter xylinum was the first strain used in the synthesis of CB, later it was reclassified as Glucanoacetobacter xylinuse more recently as Komagataeibacter xylinus (Arserim-Uçar et al., 2021; Lima et al., 2018). Currently, K. xylinus is the most investigated genus due to its ability to produce high concentrations of cellulose using various substrates as a carbon source (Fernández et al., 2019; Lappa et al., 2019; Pang et al., 2020). It is an aerobic, gram-negative rod-shaped bacterium capable of transforming glucose and other organic substrates into cellulose (Chawla et al. 2009; Wang et al., 2018a).

In the production of $\mathrm{BC}$, the Hestrin and Sharmm (HS) medium, composed of glucose, peptone, yeast extract, disodium phosphate, citric acid and pH 6 is commonly used (Cacicedo et al. 2016). Although it is a medium with excellent production of BC, 


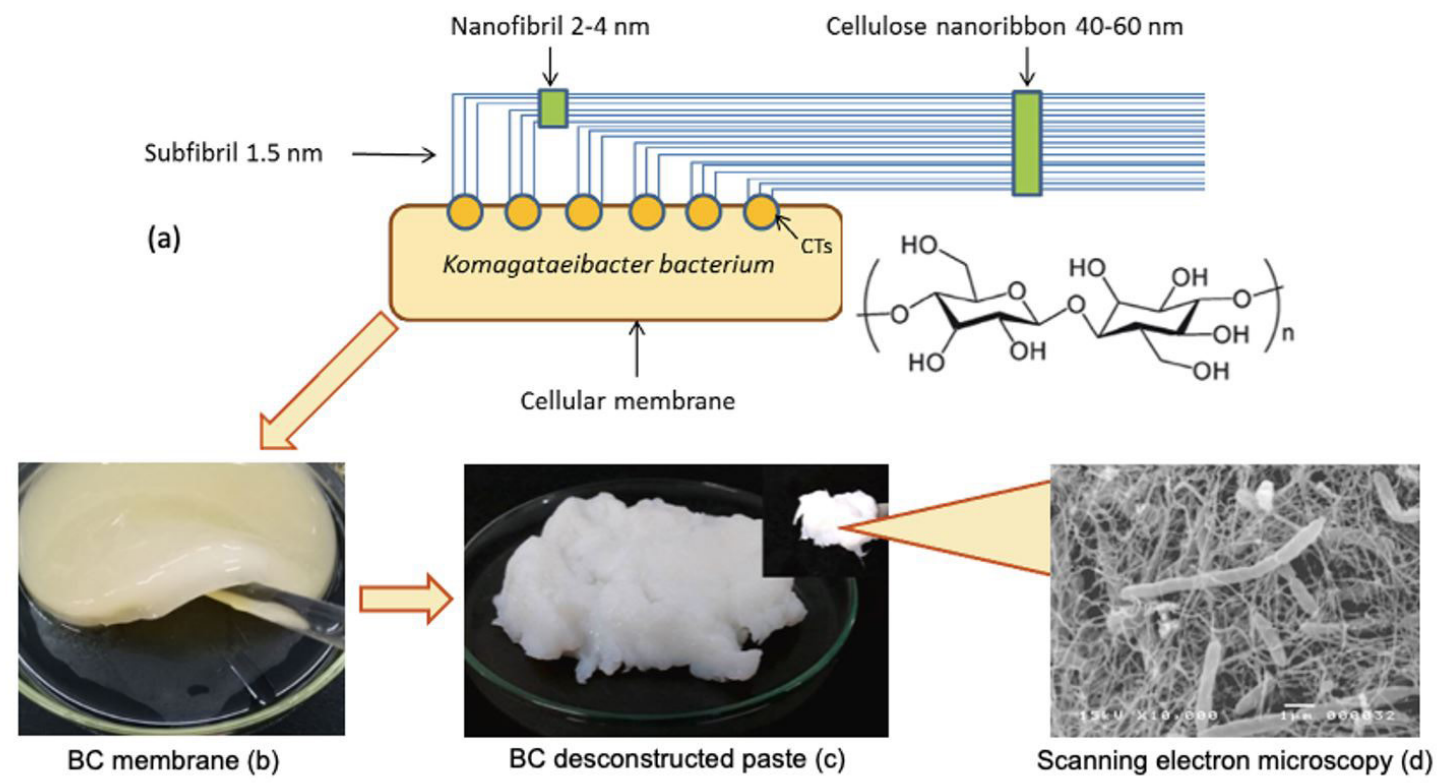

Figure 1. Formation of bacterial cellulose (a); gelatinous membrane of BC (b); deconstructed BC (c); scanning electron microscopy of BC (d). Adapted from Cacicedo et al. (2016) and Pereira et al. (2020).

its use on an industrial scale is limited due to the high cost, and therefore the development of methods to produce $\mathrm{BC}$ at a lower cost is necessary (Yim et al., 2017). BC production can be done in a static, agitated condition or in bioreactors, and each method has different macroscopic morphology, microstructure and BC properties (Pang et al., 2020; Wang et al., 2018b).

The static condition causes accumulation of $\mathrm{BC}$ at the gasliquid interface, that is, cellulose has the same shape as the surface area of the flask used in production (Gao et al., 2020; Shah et al., 2013), and its thickness increases with increasing cultivation time (Wang et al., 2019). Production is stopped when a certain thickness is formed at the air-liquid interface. This phenomenon can be caused by the lack of nutrients in the aerobic zone and low oxygen level at the bottom of the BC films (Andriani et al., 2020). According to Shi et al., (2014) static conditions are the best to maintain a regular shape and a good morphology. However, this method depends on the surface area of the cultivation medium and requires a longer production time, resulting in low productivity and making production on an industrial scale unfeasible (Huang et al., 2014; Jozala et al., 2016).

To enhance BC yield, agitated cultivation was used, so that oxygen is continuously mixed into the medium (Pang et al., 2020). According to Wang et al., (2019) this production optimizes the oxygen supply to bacteria during cultivation. $\mathrm{BC}$ produced in this condition can have irregular shapes, such as filaments, spheres, granules and fibrous threads (Cheng et al., 2009; Esa et al., 2014; Shi et al., 2014). The disadvantage of this method is the lower degree of polymerization, crystallinity and mechanical resistance when compared to static cultivation (Gullo et al., 2018; Shah et al. 2013).

The cost-benefit ratio of the culture medium in terms of $\mathrm{BC}$ yield, composition and volume of the medium should be considered for the production of $\mathrm{BC}$. The composition of the culture medium can directly affect the yield of the technological process and, therefore, is the critical point for the production of any bioproduct, including BC (Jozala et al., 2016).

According to Zhai et al., (2018), the safety of bacterial cellulose has been reviewed by the Food and Drug Administration (FDA), and since 1992 it has been recognized as safe or GRAS (Generally Recognized as Safe). Furthermore, due to its high chemical purity, it does not require any purification step that can cause changes in its structural and physico-chemical properties (Gullo et al., 2018). Thus, BC is a suitable material for technological applications, particularly in the fields of medicine and pharmacology, such as medicine capsule casing (Ullah et al., 2016), ecologically correct fabric in the textile industry (Kamiński et al., 2020), biological dressings (Stasiak-Różańska \& Płoska, 2018), in the production of contact lenses (Gullo et al., 2018), among others.

In Southwest Asia, BC is traditionally used to produce "natade-coco", a dietary fiber served as a gelatin cube used in desserts, fruit cocktails and jams (Esa et al., 2014). The final name of the product is derived from the juices used in the fermentation, with "nata-de-coco" more popularly known (Dourado et al. 2017; Piadozo, 2016). Several food applications have been developed for BC, e.g. in ice creams as a rheology modifier, in confectionery products as a fat replacer, as artificial meat for vegetarian consumers, as an emulsion stabilizer or carrier for the immobilization of probiotics and enzymes (Lappa et al., 2019; Zhai et al., 2018). The main applications of $B C$ as a fat replacer in meat products are shown in Table 1.

\section{Use in meat products}

According to Colmenero (2000), the viability of products with fat reduction depends on a series of factors that determine to what degree, from a technological point of view, fat can be 
reduce. These factors include the desired fat level, the nature of the product to be reformulated, and the type of processing required. Several strategies are being currently investigated to reduce this component in food. In this regard, $\mathrm{BC}$ has a promising role as a potential fat replacer in meat products (Fontana et al., 2017). Table 1 shows the main studies carried out with BC in the preparation of meat products. The main objective common to all investigated studies was to evaluate the effect of the addition of $\mathrm{BC}$ to the meat product to replace fat on the quality parameters of the referred product.

When it comes to the reformulation of products with substitution and/or low fat content, the texture profile must be considered. This parameter is related to the quality of the food, as it impacts the acceptance of the product by consumers (Marchetti \& Andrés, 2021; Saldaña et al., 2015). Changes in texture as a result of this reduction are a factor related to quality, which must be monitored in the development of a product (Öztürk-Kerimoğlu et al., 2020). Another important parameter to be assessed is the consumers perception of acceptance of the reformulated product. Reformulation with fat reduction and its replacement with a gel-type compound can result in a firmer, drier and more elastic product than the control (Varga-Visi \& Toxanbayeva, 2017).

Emulsion capacity refers to the amount of oil dispersed in an aqueous solution containing emulsifier, without breaking the emulsion. The duration of this process influences the stability of the emulsion and the quality of the final product, determining both the protein and fat binding as well as the tendency to exude water and fat during cooking (Âlvarez et al., 2007; McClements, 2007). The protein matrix's ability to immobilize fat and water determines cooking loss or cooking yield in emulsion-type products (Kumar, 2021). Cooking performance had a positive effect when $\mathrm{BC}$ was added to the reformulation of the product (Lin \& Lin, 2004; Marchetti et al., 2017; Yu \& Lin, 2014). In addition to the water holding capacity in the meat protein matrix, the tangled and disordered networks of cellulose fibers can crosslink with the proteins and form a 3D network, contributing to the loss of fat and water, and reducing the loss through cooking (Marchetti \& Andrés 2021).

The use of 10, 20 and 30\% BC in Chinese-style meatballs reduced the hardness of the product (Lin \& Lin, 2004). The water holding capacity of $\mathrm{BC}$ provided high humidity, favoring the reduction of hardness (Akoğlu et al., 2015). However, BC added in higher levels increased hardness in sausages with low lipid and sodium content (Marchetti et al. 2017), Sucuk type sausages (Akoğlu et al., 2015) and Frankfurt sausages (Yu \& Lin 2014). According to Shi et al., (2014), bacterial cellulose is a type of dietary fiber with gelling capacity that forms a rigid gel network and, for this reason, can provide greater hardness and stiffness in these products (Marchetti et al., 2017; Wang et al., 2018b). A similar result was obtained by Hu et al. (2016) who increased hardness in all formulations when they replaced 25, 50, 75 and $100 \%$ of regenerated cellulose in sausages. The addition of regenerated cellulose contributed to the formation of a more resistant network, which generated a harder texture.

Cooking loss is related to the protein matrix's ability to retain water and fat in emulsion-type products (Varga-Visi \&
Toxanbayeva, 2017). However, in foods with fat replacement, this process may not occur due to the reduction of the emulsification capacity of the non-meat ingredients used as substitutes (Kumar, 2021). In this regard, dietary fibers are effective due to their ability to retain water and fat (Álvarez \& Barbut, 2013; Talukder, 2015).

Frankfurt-type sausages (Marchetti et al., 2017), Chinese-type meatballs (Lin \& Lin, 2004) and mahi-mahi surimi (Lin et al., 2011) showed a water retention capacity higher than that of the control formulation and the original structure of the products was maintained after using BC as a fat replacer. The same occurred with the addition of $2 \mathrm{~g} / 100 \mathrm{~g}$ of different sources of vegetable cellulose in sausages pre-emulsified with soybean oil, in which the water retention capacity increased when cellulose was included (Li et al., 2020).

According to Kumar (2021) some non-meat ingredients may present greater water retention due to their ability to interact with the polar groups of the protein matrix. In Bologna-type mortadella, when inulin-based emulsion gels were used, the exudated liquid was close to zero due to the water and fat retention capacity, a characteristic related to inulin (Paglarini et al., 2021). In addition to their technological benefits, the addition of dietary fiber as a substitute is known because they are functional ingredients that improve the nutritional properties of reformulated products (Paglarini et al., 2021; Talukder, 2015).

Frankfurt-type sausages with 10, 20 and 30\% BC developed by Yu \& Lin (2014) obtained lower values for loss of cooking, when compared to the control formulation. In the case of sausages with low sodium and fat content to which $\mathrm{BC}$ was added, cooking performance results similar to those of the control formulation were obtained (Marchetti et al., 2017). Ström (2013), who used microfibrillated cellulose in hamburgers, reported that cooking losses were reduced when a higher content of hydrocolloid was added. In contrast, in Chinese-style meatballs, the increase in levels of 10 to $30 \%$ of "nata" resulted in a significant increase in cooking loss compared to the control formulation (Lin \& Lin, 2004). It is possible that the cooking loss was caused by the fact that $\mathrm{BC}$ was no longer able to retain water in the protein matrix during emulsification and heating, resulting in the release of water (Yu \& Lin, 2014).

Color is an important parameter that affects consumers' purchasing decision (Marchetti \& Andrés, 2021; Meza et al., 2020; Y. Wang et al. 2018b). According to Kumar (2021), color attributes depend on the light scattering properties of a food product surface affected by different ingredients. Sausages with low lipid and sodium content (Marchetti et al. 2017) and Sucuk sausages (Akoğlu et al., 2015) showed a reduction in the $\mathrm{L}^{*}$ parameter of the samples with the addition of "nata". The reduction of animal fat results in decrease in the $\mathrm{L}^{*}$ parameter, which is related to the lack of the shiny aspect associated with the presence of fat. The opposite was observed in Frankfurt sausages where there was an increase in the parameter $L^{*}$ in the samples added with "nata" compared to the control formulation. In this case, luminosity increased due to the addition of water (Yu \& Lin, 2014).

Sucuk sausages had no differences in odor, color, flavor and texture compared to the control treatment. The treatment with $20 \%$ BC showed an increase in hardness and obtained a 
reduced acceptability value. This can be explained by the nonaddition of fat ( $0 \%$ fat and $20 \%$ of BC) in the formulation, which increased hardness as observed in the texture profile parameter (Akoğlu et al., 2015).

Frankfurt sausages with $30 \%$ BC had the least firmness and the greatest juiciness compared to other formulations. The explanation for this is that the water content present in the cellulose favored a greater softening. However, despite these differences, the sausage obtained good sensory acceptance, not differing statistically when compared to the sausages of the control formulation (Yu \& Lin, 2014). The same occurred in the samples of Chinese-type meatballs. The sample with $30 \% \mathrm{BC}$ was the least firm and the most juicy, and with the least acceptance in the general acceptability attribute, whereas the formulations of 10 and $20 \%$ BC did not differ from the control sample.

As for sensory acceptance, the main effect of $\mathrm{BC}$ could be related to the texture of the reformulated product, since it is a tasteless, odorless and colorless product (Marchetti \& Andrés, 2021).

Based on the results of the studies analyzed in Table 1, it can be concluded that it is possible to produce sausage products with low fat content and with properties very similar to commercial products. The inclusion of 10 or $20 \%$ of BC proved to be successful in replacing fat, as it did not change the color, softness and flavor of the analyzed products.

\section{Future perceptions}

Meat products are an excellent source of nutrients necessary for health. However, due to the high fat content they are associated with chronic diseases. Currently, the most favorable attempt to deal with this issue is based on the reformulation of these products, reducing the fat content of the composition. In the studies reported in the present review, bacterial cellulose proved to be a promising ingredient as a fat replacer in meat products. However, despite the possible applications of $\mathrm{BC}$ as a fat replacer, challenges still need to be solved. The space required for production, the improvement in yield and the cost of production are some of the obstacles related to the application of $\mathrm{BC}$ on an industrial scale (Andriani et al., 2020; Cacicedo et al., 2016; Esa et al., 2014).

The future objectives of the development of research in BC are investigating ways to improve production yield, exploring new methodologies to determine another bacterial strain with a higher rate of yield and investigating possible ways to reduce production costs. To solve this problem, we depend on advancements in biotechnology, in order to expand its use in the food segment.

\section{References}

Akoğlu, A., Çakir, İ., Akoğlu, İ. T., Karahan, A. G., \& Çakmakçi, M. L. (2015). Effect of bacterial cellulose as a fat replacer on some quality characteristics of fat reduced sucuk. Gida: The Journal of Food, 40(3), 133-140.

Álvarez, D., \& Barbut, S. (2013). Effect of inulin, $\beta$-Glucan and their mixtures on emulsion stability, color and textural parameters of cooked meat batters. Meat Science, 94(3), 320-327. http://dx.doi. org/10.1016/j.meatsci.2013.02.011. PMid:23567131.

Álvarez, D., Castillo Zambudio, M., Garrido Fernández, M., Bañón Arias, S., Nieto López, G., Díaz Molins, P., \& Payne, F. (2007). Efecto de la composición y el de procesado sobre las propiedades tecnológicas y ópticas de las emulsiones cárnicas. Anales de Veterinaria de Murcia, 34(23), 25-34.

Alves, L. A. A. S., Lorenzo, J. M., Gonçalves, C. A. A., Santos, B. A., Heck, R. T., Cichoski, A. J., \& Campagnol, P. C. B. (2016). Production of healthier bologna type sausages using pork skin and green banana flour as a fat replacers. Meat Science, 121, 73-78. http://dx.doi. org/10.1016/j.meatsci.2016.06.001. PMid:27288899.

Andriani, D., Apriyana, A. Y., \& Karina, M. (2020). The optimization of bacterial cellulose production and its applications: a review. Cellulose, 27(12), 6747-6766. http://dx.doi.org/10.1007/s10570-020-03273-9.

Arserim-Uçar, D. K., Korel, F., Liu, L. S., \& Yam, K. L. (2021). Characterization of bacterial cellulose nanocrystals: effect of acid treatments and neutralization. Food Chemistry, 336, 127597. http:// dx.doi.org/10.1016/j.foodchem.2020.127597. PMid:32763732.

Barbut, S., Marangoni, A. G., Thode, U., \& Tiensa, B. E. (2019). Using canola oil organogels as fat replacement in liver pâté. Journal of Food Science, 84(9), 2646-2651. http://dx.doi.org/10.1111/17503841.14753. PMid:31429478.

Bolger, Z., Brunton, N. P., Lyng, J. G., \& Monahan, F. J. (2017). Comminuted meat products-consumption, composition, and approaches to healthier formulations. Food Reviews International, 33(2), 143-166. http://dx.doi.org/10.1080/87559129.2016.1149861.

Brewer, M. S. (2012). Reducing the fat content in ground beef without sacrificing quality: a review. Meat Science, 91(4), 385-395. http:// dx.doi.org/10.1016/j.meatsci.2012.02.024. PMid:22444664.

Brown, A. J. (1886). Brown on acetic ferment. Journal of the Chemical Society Transactions, 49(432), 432-439. http://dx.doi.org/10.1039/ CT8864900432.

Cacicedo, M. L., Castro, M. C., Servetas, I., Bosnea, L., Boura, K., Tsafrakidou, P., Dima, A., Terpou, A., Koutinas, A., \& Castro, G. R. (2016). Progress in bacterial cellulose matrices for biotechnological applications. Bioresource Technology, 213, 172-180. http://dx.doi. org/10.1016/j.biortech.2016.02.071. PMid:26927233.

Calvo, F., Gómez, J. M., Ricardez-Sandoval, L., \& Alvarez, O. (2020). Integrated design of emulsified cosmetic products: a review. Chemical Engineering Research \& Design, 161, 279-303. http://dx.doi. org/10.1016/j.cherd.2020.07.014.

Câmara, A. K. F. I., Okuro, P. K., Cunha, R. L., Herrero, A. M., RuizCapillas, C., \& Pollonio, M. A. R. (2020). Chia (Salvia hispanica L.) mucilage as a new fat substitute in emulsified meat products: technological, physicochemical, and rheological characterization. LWT, 125, 109193. http://dx.doi.org/10.1016/j.lwt.2020.109193.

Chawla, P. R., Bajaj, I. B., Survase, S. A., \& Singhal, R. S. (2009). Microbial cellulose: fermentative production and applications. Food Technology and Biotechnology, 47(2), 107-124.

Cheng, K. C., Catchmark, J. M., \& Demirci, A. (2009). Enhanced production of bacterial cellulose by using a biofilm reactor and its material property analysis. Journal of Biological Engineering, 3, 12. http://dx.doi.org/10.1186/1754-1611-3-12. PMid:19630969.

Choi, Y. S., Choi, J. H., Han, D. J., Kim, H. Y., Lee, M. A., Kim, H. W., Jeong, J. Y., \& Kim, C. J. (2009). Characteristics of low-fat meat emulsion systems with pork fat replaced by vegetable oils and rice bran fiber. Meat Science, 82(2), 266-271. http://dx.doi.org/10.1016/j. meatsci.2009.01.019. PMid:20416740. 
Colmenero, F. J. (2000). Relevant factors in strategies for fat reduction in meat products. Trends in Food Science \& Technology, 11(2), 56-66. http://dx.doi.org/10.1016/S0924-2244(00)00042-X.

Dong, Y. D., Zhang, H., Zhong, G. J., Yao, G., \& Lai, B. (2021). Cellulose/ carbon composites and their applications in water treatment - a review. Chemical Engineering Journal, 405, 126980. http://dx.doi. org/10.1016/j.cej.2020.126980.

Dourado, F., Gama, M., \& Rodrigues, A. C. (2017). A Review on the toxicology and dietetic role of bacterial cellulose. Toxicology Reports, 4, 543-553. http://dx.doi.org/10.1016/j.toxrep.2017.09.005. PMid:29090119.

Esa, F., Tasirin, S. M., \& Rahman, N. A. (2014). Overview of bacterial cellulose production and application. Agriculture and Agricultural Science Procedia, 2, 113-119. http://dx.doi.org/10.1016/j.aaspro.2014.11.017.

Fan, R., Zhou, D., \& Cao, X. (2020). Evaluation of oat $\beta$-glucan-marine collagen peptide mixed gel and its application as the fat replacer in the sausage products. PLoS One, 15(5), e0233447. http://dx.doi. org/10.1371/journal.pone.0233447. PMid:32442194.

Felfoul, I., Bornaz, S., Baccouche, A., Sahli, A., \& Attia, H. (2015). Low-fat Gouda cheese made from bovine milk-olive oil emulsion: physicochemical and sensory attributes. Journal of Food Science and Technology, 52(10), 6749-6755. http://dx.doi.org/10.1007/s13197015-1736-0. PMid:26396425.

Fernández, J., Morena, A. G., Valenzuela, S. V., Pastor, F. I. J., Díaz, P., \& Martínez, J. (2019). Microbial cellulose from a Komagataeibacter intermedius strain isolated from commercial wine vinegar. Journal of Polymers and the Environment, 27(5), 956-967. http://dx.doi. org/10.1007/s10924-019-01403-4.

Fontana, J. D., Koop, H. S., Tiboni, M., Grzybowski, A., Pereira, A., Kruger, C. D., Silva, M. G. R., \& Wielewski, L. P. (2017). New insights on bacterial cellulose. In A. M. Grumezescu \& A. M. Holban (Eds.), Food biosynthesis (pp. 213-249). Cambridge: Elsevier Academic Press. http://dx.doi.org/10.1016/B978-0-12-811372-1.00007-5.

Gallegos, A. M. A., Carrera, S. H., Parra, R., Keshavarz, T., \& Iqbal, H. M. N. (2016). Bacterial cellulose: a sustainable source to develop value-added products - a review. BioResources, 11(2), 5641-5655. http://dx.doi.org/10.15376/biores.11.2.Gallegos.

Gao, G., Cao, Y., Zhang, Y., Wu, M., Ma, T., \& Li, G. (2020). In situ production of bacterial cellulose/xanthan gum nanocomposites with enhanced productivity and properties using Enterobacter sp. FY-07. Carbohydrate Polymers, 248, 116788. http://dx.doi.org/10.1016/j. carbpol.2020.116788. PMid:32919576.

Gómez-Estaca, J., Herrero, A. M., Herranz, B., Álvarez, M. D., JiménezColmenero, F., \& Cofrades, S. (2019). Characterization of ethyl cellulose and beeswax oleogels and their suitability as fat replacers in healthier lipid pâtés development. Food Hydrocolloids, 87, 960969. http://dx.doi.org/10.1016/j.foodhyd.2018.09.029.

Gordon, A. (1993). Studying comminuted meat products using corroborative techniques. Food Research International, 26(3), 209216. http://dx.doi.org/10.1016/0963-9969(93)90055-N.

Gullo, M., La China, S., Falcone, P. M., \& Giudici, P. (2018). Biotechnological production of cellulose by acetic acid bacteria: current state and perspectives. Applied Microbiology and Biotechnology, 102(16), 68856898. http://dx.doi.org/10.1007/s00253-018-9164-5. PMid:29926141.

Guo, Y., Zhang, X., Hao, W., Xie, Y., Chen, L., Li, Z., Zhu, B., \& Feng, X. (2018). Nano-bacterial cellulose/soy protein isolate complex gel as fat substitutes in ice cream model. Carbohydrate Polymers, 198, 620-630. http://dx.doi.org/10.1016/j.carbpol.2018.06.078. PMid:30093042.

Güzel, M., \& Akpınar, Ö. (2020). Preparation and characterization of bacterial cellulose produced from fruit and vegetable peels by
Komagataeibacter hansenii GA2016. International Journal of Biological Macromolecules, 162, 1597-1604. http://dx.doi.org/10.1016/j. ijbiomac.2020.08.049. PMid:32777420.

Hu, H., Pereira, J., Xing, L., Hu, Y., Qiao, C.-L., Zhou, G., \& Zhang, W. (2016). Effects of regenerated cellulose emulsion on the quality of emulsified sausage. $L W T, 70,315-321$. http://dx.doi.org/10.1016/j. lwt.2016.02.055.

Huang, Y., Zhu, C., Yang, J., Nie, Y., Chen, C., \& Sun, D. (2014). Recent advances in bacterial cellulose. Cellulose, 21(1), 1-30. http://dx.doi. org/10.1007/s10570-013-0088-z.

Jacek, P., Dourado, F., Gama, M., \& Bielecki, S. (2019). Molecular aspects of bacterial nanocellulose biosynthesis. Microbial Biotechnology, 12(4), 633-649. http://dx.doi.org/10.1111/1751-7915.13386. PMid:30883026.

Jiang, J., \& Xiong, Y. L. (2015). Role of interfacial protein membrane in oxidative stability of vegetable oil substitution emulsions applicable to nutritionally modified sausage. Meat Science, 109, 56-65. http:// dx.doi.org/10.1016/j.meatsci.2015.05.011. PMid:26008711.

Jozala, A. F., Lencastre-Novaes, L. C., Lopes, A. M., Santos-Ebinuma, V. C., Mazzola, P. G., Pessoa, A. Jr, Grotto, D., Gerenutti, M., \& Chaud, M. V. (2016). Bacterial nanocellulose production and application: a 10-year overview. Applied Microbiology and Biotechnology, 100(5), 2063-2072. http://dx.doi.org/10.1007/s00253-015-7243-4. PMid:26743657.

Kamiński, K., Jarosz, M., Grudzień, J., Pawlik, J., Zastawnik, F., Pandyra, P., \& Kołodziejczyk, A. M. (2020). Hydrogel bacterial cellulose: a path to improved materials for new eco-friendly textiles. Cellulose, 27(9), 5353-5365. http://dx.doi.org/10.1007/s10570-020-03128-3.

Kim, T. K., Lee, M. H., Kim, S. M., Kim, M. J., Jung, S., Yong, H. I., \& Choi, Y. S. (2021). Physiochemical properties of reduced-fat duck meat emulsion systems: effects of preemulsification with vegetable oils and duck skin. Poultry Science, 100(2), 1291-1298. http://dx.doi. org/10.1016/j.psj.2020.10.044. PMid:33518086.

Klemm, D., Schumann, D., Udhardt, U., \& Marsch, S. (2001). Bacterial synthesized cellulose - artificial blood vessels for microsurgery. Progress in Polymer Science, 26(9), 1561-1603. http://dx.doi.org/10.1016/ S0079-6700(01)00021-1.

Kumar, Y. (2021). Development of Low-Fat/Reduced-Fat Processed Meat Products using Fat Replacers and Analogues. Food Reviews International, 37(3), 296-312. http://dx.doi.org/10.1080/87559129 .2019 .1704001 .

Kwon, H. C., Shin, D. M., Yune, J. H., Jeong, C. H., \& Han, S. G. (2021). Evaluation of gels formulated with whey proteins and sodium dodecyl sulfate as a fat replacer in low-fat sausage. Food Chemistry, 337, 127682. http://dx.doi.org/10.1016/j.foodchem.2020.127682. PMid:32795852.

Lappa, I. K., Papadaki, A., Kachrimanidou, V., Terpou, A., Koulougliotis, D., Eriotou, E., \& Kopsahelis, N. (2019). Cheese whey processing: integrated biorefinery concepts and emerging food applications. Foods, 8(8), 347. http://dx.doi.org/10.3390/foods8080347. PMid:31443236.

Li, Q., Chen, P., Li, Y., Li, B., \& Liu, S. (2020). Construction of cellulosebased Pickering stabilizer as a novel interfacial antioxidant: a bioinspired oxygen protection strategy. Carbohydrate Polymers, 229, 115395. http://dx.doi.org/10.1016/j.carbpol.2019.115395. PMid:31826411.

Lima, H. L. S., Gonçalves, C., Cerqueira, M. Â., Nascimento, E. S., Gama, M. F., Rosa, M. F., Borges, M. F., Pastrana, L. M., \& Brígida, A. I. S. (2018). Bacterial cellulose nanofiber-based films incorporating gelatin hydrolysate from tilapia skin: production, characterization and cytotoxicity assessment. Cellulose, 25(10), 6011-6029. http:// dx.doi.org/10.1007/s10570-018-1983-0. 
Lin, K. W., \& Lin, H. Y. (2004). Quality characteristics of chinese-style meatball containing bacterial cellulose (nata). Journal of Food Science, 69(3), SNQ107-SNQ111.http://dx.doi.org/10.1111/j.1365-2621.2004. tb13378.x.

Lin, S., Chen, L.-C., \& Chen, H.-H. (2011). Physical characteristics of surimi and bacterial cellulose composite gel. Journal of Food Process Engineering, 34(4), 1363-1379. http://dx.doi.org/10.1111/j.17454530.2009.00533.x.

López-Pedrouso, M., Lorenzo, J. M., Gullón, B., Campagnol, P. C. B., \& Franco, D. (2021). Novel strategy for developing healthy meat products replacing saturated fat with oleogels. Current Opinion in Food Science, 40, 40-45. http://dx.doi.org/10.1016/j.cofs.2020.06.003.

Marchetti, L., \& Andrés, S. C. (2021). Use of nanocellulose in meat products. Current Opinion in Food Science, 38, 96-101. http://dx.doi. org/10.1016/j.cofs.2020.11.003.

Marchetti, L., Muzzio, B., Cerrutti, P., Andrés, S. C., \& Califano, A. N. (2017). Bacterial nanocellulose as novel additive in low-lipid low-sodium meat sausages. Effect on quality and stability. Food Structure, 14, 52-59. http://dx.doi.org/10.1016/j.foostr.2017.06.004.

McClements, D. J. (2007). Critical review of techniques and methodologies for characterization of emulsion stability. Critical Reviews in Food Science and Nutrition, 47(7), 611-649. http://dx.doi. org/10.1080/10408390701289292. PMid:17943495.

Meza, G., Sanchez, C. N., Orvananos-Guerrero, M. T., \& DominguezSoberanes, J. (2020). Analysis of Meat Color Change using Computer Vision. 2020 IEEE International Autumn Meeting on Power, Electronics and Computing, ROPEC 2020. New York: Institute of Electrical and Electronics Engineers. http://dx.doi.org/10.1109/ ROPEC50909.2020.9258756

Naloka, K., Matsushita, K., \& Theeragool, G. (2020). Enhanced ultrafine nanofibril biosynthesis of bacterial nanocellulose using a low-cost material by the adapted strain of Komagataeibacter xylinus MSKU 12. International Journal of Biological Macromolecules, 150, 1113-1120. http://dx.doi.org/10.1016/j.ijbiomac.2019.10.117. PMid:31739023.

Okiyama, A., Motoki, M., \& Yamanaka, S. (1993). Bacterial cellulose IV. Application to processed foods. Food Hydrocolloids, 6(6), 503-511. http://dx.doi.org/10.1016/S0268-005X(09)80074-X.

Öztürk-Kerimoğlu, B., Kavuşan, H. S., Tabak, D., \& Serdaroğlu, M. (2020). Formulating reduced-fat sausages with quinoa or teff flours: effects on emulsion characteristics and product quality. Food Science of Animal Resources, 40(5), 710-721. http://dx.doi.org/10.5851/ kosfa.2020.e46. PMid:32968724.

Paglarini, C. S., Vidal, V. A. S., Ribeiro, W., Badan Ribeiro, A. P., Bernardinelli, O. D., Herrero, A. M., Ruiz-Capillas, C., Sabadini, E., \& Pollonio, M. A. R. (2021). Using inulin-based emulsion gels as fat substitute in salt reduced Bologna sausage. Journal of the Science of Food and Agriculture, 101(2), 505-517. http://dx.doi.org/10.1002/ jsfa.10659. PMid:32648307.

Pang, M., Huang, Y., Meng, F., Zhuang, Y., Liu, H., Du, M., Ma, Q., Wang, Q., Chen, Z., Chen, L., Cai, T., \& Cai, Y. (2020). Application of bacterial cellulose in skin and bone tissue engineering. European Polymer Journal, 122, 109365. http://dx.doi.org/10.1016/j. eurpolymj.2019.109365.

Pereira, J., Brohi, S. A., Malairaj, S., Zhang, W., \& Zhou, G. H. (2020). Quality of fat-reduced frankfurter formulated with unripe banana by-products and pre-emulsified sunflower oil. International Journal of Food Properties, 23(1), 420-433. http://dx.doi.org/10.1080/1094 2912.2020.1733014.

Piadozo, M. E. S. (2016). Nata de Coco Industry in the Philippines. In M. Gama, F. Dourado \& S. Bielecki (Eds.), Bacterial nanocellulose: from biotechnology to bio-economy (pp. 215-229). Amsterdam: Elsevier. http://dx.doi.org/10.1016/B978-0-444-63458-0.00013-5

Pinton, M. B., Correa, L. P., Facchi, M. M. X., Heck, R. T., Leães, Y. S. V., Cichoski, A. J., Lorenzo, J. M., Dos Santos, M., Pollonio, M. A. R., \& Campagnol, P. C. B. (2019). Ultrasound: a new approach to reduce phosphate content of meat emulsions. Meat Science, 152, 88-95. http://dx.doi.org/10.1016/j.meatsci.2019.02.010. PMid:30836267.

Rodrigues, I., Gonçalves, L. A., Carvalho, F., Pires, M., Rocha, Y. J. P., Barros, J. C., Carvalho, L. T. \& Trindade, M. A. (2020). Understanding salt reduction in fat-reduced hot dog sausages: network structure, emulsion stability and consumer acceptance. Food Science \& Technology International, 26(2), 123-131. http:// dx.doi.org/10.1177/1082013219872677. PMid:31510800.

Saldaña, E., Behrens, J. H., Serrano, J. S., Ribeiro, F., de Almeida, M. A., \& Contreras-Castillo, C. J. (2015). Microstructure, texture profile and descriptive analysis of texture for traditional and light mortadella. Food Structure, 6, 13-20. http://dx.doi.org/10.1016/j. foostr.2015.09.001.

Santos, M., Ozaki, M. M., Ribeiro, W. O., Paglarini, C. S., Vidal, V. A. S., Campagnol, P. C. B., \& Pollonio, M. A. R. (2020). Emulsion gels based on pork skin and dietary fibers as animal fat replacers in meat emulsions: an adding value strategy to byproducts. $L W T, 120$, 108895. http://dx.doi.org/10.1016/j.lwt.2019.108895.

Shah, N., Ul-Islam, M., Khattak, W. A., \& Park, J. K. (2013). Overview of bacterial cellulose composites: a multipurpose advanced material. Carbohydrate Polymers, 98(2), 1585-1598. http://dx.doi.org/10.1016/j. carbpol.2013.08.018. PMid:24053844.

Shi, Z., Zhang, Y., Phillips, G. O., \& Yang, G. (2014). Utilization of bacterial cellulose in food. Food Hydrocolloids, 35, 539-545. http:// dx.doi.org/10.1016/j.foodhyd.2013.07.012.

Silva-Vazquez, R., Flores-Giron, E., Quintero-Ramos, A., Hume, M. E., \& Mendez-Zamora, G. (2018). Effect of inulin and pectin on physicochemical characteristics and emulsion stability of meat batters. CyTA: Journal of Food, 16(1), 306-310. http://dx.doi.org/1 0.1080/19476337.2017.1403490.

Stasiak-Różańska, L., \& Płoska, J. (2018). Study on the use of microbial cellulose as a biocarrier for 1,3-dihydroxy-2-propanone and its potential application in industry. Polymers, 10(4), 438. http://dx.doi. org/10.3390/polym10040438. PMid:30966473.

Ström, G., Öhgren, C., \& Ankerfors, M. (2013). Nanocellulose as an additive in foodstuff. Innventia Rep, 403, 1-25.

Szpicer, A., Onopiuk, A., Półtorak, A., \& Wierzbicka, A. (2020). The influence of oat $\beta$-glucan content on the physicochemical and sensory properties of low-fat beef burgers. CyTA: Journal of Food, 18(1), 315-327. http://dx.doi.org/10.1080/19476337.2020.1750095.

Talukder, S. (2015). Effect of dietary fiber on properties and acceptance of meat products: a review. Critical Reviews in Food Science and Nutrition, 55(7), 1005-1011. http://dx.doi.org/10.1080/10408398. 2012.682230. PMid:24915339.

Tufeanu, R., \& Tita, O. (2016). Possibilities to develop low-fat products: a review. Acta Universitatis Cibiniensis. Series E: Food Technology, 20(1), 3-19. http://dx.doi.org/10.1515/aucft-2016-0001.

Ullah, H., Santos, H. A., \& Khan, T. (2016). Applications of bacterial cellulose in food, cosmetics and drug delivery. Cellulose, 23(4), 2291-2314. http://dx.doi.org/10.1007/s10570-016-0986-y.

Varga-Visi, É., \& Toxanbayeva, B. (2017). Application of fat replacers and their effect on quality of comminuted meat products with low lipid content: a review. Acta Alimentaria, 46(2), 181-186. http:// dx.doi.org/10.1556/066.2016.0008. 
Volova, T. G., Prudnikova, S. V., Sukovatyi, A. G., \& Shishatskaya, E. I. (2018). Production and properties of bacterial cellulose by the strain Komagataeibacter xylinus B-12068. Applied Microbiology and Biotechnology, 102(17), 7417-7428. http://dx.doi.org/10.1007/ s00253-018-9198-8. PMid:29982923.

Wang, J., Tavakoli, J., \& Tang, Y. (2019). Bacterial cellulose production, properties and applications with different culture methods - a review. Carbohydrate Polymers, 219, 63-76. http://dx.doi.org/10.1016/j. carbpol.2019.05.008. PMid:31151547.

Wang, X., Guo, C., Hao, W., Ullah, N., Chen, L., Li, Z., \& Feng, X. (2018b). Development and characterization of agar-based edible films reinforced with nano-bacterial cellulose. International Journal of Biological Macromolecules, 118(Pt A), 722-730. http://dx.doi. org/10.1016/j.ijbiomac.2018.06.089. PMid:29944938.

Wang, Y., Wang, W., Jia, H., Gao, G., Wang, X., Zhang, X., \& Wang, Y. (2018a). Using cellulose nanofibers and its palm oil pickering emulsion as fat substitutes in emulsified sausage. Journal of Food Science, 83(6), 1740-1747. http://dx.doi.org/10.1111/1750-3841.14164. PMid:29745986.
Warshaw, H., Franz, M., Powers, M. A., \& Wheeler, M. (1996). Fat replacers: their use in foods and role in diabetes medical nutrition therapy. Diabetes Care, 19(11), 1294-1301. http://dx.doi.org/10.2337/ diacare.19.11.1294. PMid:8908400.

Yim, S. M., Song, J. E., \& Kim, H. R. (2017). Production and characterization of bacterial cellulose fabrics by nitrogen sources of tea and carbon sources of sugar. Process Biochemistry, 59, 26-36. http://dx.doi. org/10.1016/j.procbio.2016.07.001.

Yousefi, M., Khorshidian, N., \& Hosseini, H. (2018). An overview of the functionality of inulin in meat and poultry products. Nutrition \& Food Science, 48(5), 819-835. http://dx.doi.org/10.1108/NFS-11-2017-0253.

Yu, S.-Y., \& Lin, K.-W. (2014). Influence of bacterial cellulose (nata) on the physicochemical and sensory properties of frankfurter. Journal of Food Science, 79(6), C1117-C1122. http://dx.doi.org/10.1111/17503841.12494. PMid:24888552.

Zhai, X., Lin, D., Zhao, Y., Li, W., \& Yang, X. (2018). Enhanced anti-obesity effects of bacterial cellulose combined with konjac glucomannan in high-fat diet-fed C57BL/6J mice. Food \& Function, 9(10), 52605272. http://dx.doi.org/10.1039/C8FO01211C. PMid:30238111. 